\title{
ANALISIS KESALAHAN STRUKTUR DAN PEMAKAIAN BAHASA INDONESIA PADA TEKS PERSUASI KARANGAN SISWA KELAS 8 SMP DI SURAKARTA
}

\author{
Nesa Amelia Subekti ${ }^{1}$, Sumarwati ${ }^{2}$, Raheni Suhita ${ }^{3}$ \\ Universitas Sebelas Maret \\ E-mail: nesamelias289@gmail.com¹, watik_uns@ymail.com², \\ raheni_suhita@yahoo.com ${ }^{3}$
}

\begin{abstract}
Abstrak: Hasil penelitian menunjukkan bahwa terdapat kesalahan struktur dan pemakaian bahasa Indonesia pada teks persuasi karangan siswa kelas 8 SMP di Surakarta. Kesalahan tersebut terjadi pada struktur teks persuasi yang tidak lengkap terutama pada bagian penegasan ulang. Kesalahan pemakaian bahasa Indonesia meliputi kesalahan penggunaan ejaan, kesalahan pemilihan diksi, dan kesalahan penulisan kalimat. Kesalahan penggunaan ejaan yang paling banyak ditemukan adalah kesalahan pemakaian huruf kapital dan kesalahan penggunaan tanda baca terutama tanda baca titik dan koma. Kesalahan pemilihan diksi yang paling banyak ditemukan meliputi pemilihan diksi yang tidak tepat dan diksi yang tidak baku. Kesalahan penulisan kalimat terutama disebabkan oleh kalimat yang tidak efektif. Kesalahan-kesalahan tersebut disebabkan oleh beberapa faktor. Faktor tersebut antara lain (1) siswa tidak memahami struktur teks persuasi, (2) siswa minim pengetahuan tentang ejaan dan diksi, (3) kurangnya contoh yang diberikan guru, (4) kurangnya latihan mengarang, dan (5) kurangnya motivasi siswa untuk menulis.
\end{abstract}

Kata Kunci: kalimat efektif, kesalahan berbahasa, kesalahan ejaan, pemilihan diksi, teks persuasi

\section{AN ANALYSIS OF STRUCTURAL AND INDONESIAN LANGUAGE USAGE ERROR ON THE PERSUATION TEXT OF STUDENTS AT GRADE 8 OF JUNIOR HIGH SCHOOL IN SURAKARTA}

\begin{abstract}
The results shows that there are structure error and Indonesian language usage error on the persuasion text written by students at grade 8 of Junior High School in Surakarta. Those errors on the incomplete structure of persuasion text especially in the reaffirmation section. The Indonesian language usage errors include spelling error, diction error, and grammatical error. The most common errors of spelling comprises capital letters and punctuation marks usage particularly full stop and comma. The most-found errors of diction comprises improper diction selection and nonstandard diction. Grammatical error is mainly caused by ineffective sentence. Those errors are caused by some factors. The factors are (1) students do not understand the structure of persuasion text, (2) students have lack of spelling and diction knowledge, (3) the lack of examples given by teacher, (4) the lack of writing practice, and (5) student lack motivation within writing.
\end{abstract}

Keywords: effective sentence, language errors, spelling errors, diction election, persuasion text

\section{PENDAHULUAN}

Bahasa Indonesia merupakan bahasa resmi sehingga wajib digunakan dalam penyelenggaraan pendidikan di sekolah. Sekolah adalah wadah untuk meningkatkan kualitas sumber daya

BASASTRA Jurnal Bahasa, Sastra, dan Pengajarannya

Volume 8 Nomor 2, Oktober 2020, P-ISSN 2302-6405, E-ISSN 2714-9765 
manusia (Purwaningrum, Andayani, Purwadi, 2013: 1). Pada pembelajaran bahasa Indonesia, ada empat keterampilan berbahasa yang harus dikuasai oleh siswa, yaitu keterampilan menyimak, keterampilan berbicara, keterampilan membaca, dan keterampilan (Dalman, 2018:2). Menulis adalah salah satu keterampilan berbahasa dalam pembelajaran Bahasa Indonesia yang harus dimiliki siswa.

Nurgiyantoro (2014:422) mengemukakan bahwa keterampilan menulis merupakan keterampilan yang sulit dikuasai dibanding keterampilan berbahasa lainnya, bahkan oleh penutur asli bahasa tersebut. Senada dengan hasil temuan Javed, Juan, dan Nazli (2014:130) bahwa menulis lebih sulit dibanding kemampuan berbahasa lainnya karena menulis membutuhkan penguasaan berbagai unsur kebahasaan di luar bahasa itu sendiri.

Hampir semua jenis tulisan atau karangan diajarkan melalui pembelajaran Bahasa Indonesia, salah satunya yaitu karangan persuasi. Persuasi merupakan seni verbal yang memiliki tujuan untuk meyakinkan orang lain agar melakukan sesuatu yang dikehendaki oleh penulis pada saat itu atau waktu yang akan datang (Keraf, 2007: 118). Melalui pembelajaran bahasa Indonesia, harusnya siswa mampu menulis karangan persuasi yang baik, minimal memenuhi struktur dan memiliki tata penulisan yang sesuai dengan pedoman ejaan. Namun, pada kenyataannya masih banyak sekali siswa yang kesulitan menulis dan belum mampu menulis atau membuat karangan dengan baik.

Selaras dengan hasil penelitian Angriani dan Maharani (2019: 684) yang menyatakan bahwa kualitas menulis teks persuasi oleh siswa masih tergolong rendah karena kurangnya kemauan siswa dan usaha guru untuk menarik perhatian siswa dalam proses pembelajaran. Banyak guru menganggap pembelajaran bahasa hanya berorientasi pada nilai. Septiana, Sumarwati, Suyitno (2015: 3) mengungkapkan bahwa rendahnya kemampuan menulis di kalangan siswa sekolah menengah pertama merupakan salah satu dari sekian banyaknya masalah yang terjadi di dunia pendidikan. Kegiatan menulis biasanya hanya dilakukan untuk memenuhi persyaratan nilai mata pelajaran Bahasa Indonesia saja. Pemikiran seperti inilah yang akhirnya membuat siswa kurang memiliki motivasi untuk belajar menulis.

Kesalahan yang dilakukan siswa dalam proses menulis memang wajar mengingat siswa masih dalam tahap belajar. Namun, masih banyak siswa yang tidak mengetahui bahwasanya ketika menulis, mereka sering melakukan kesalahan berbahasa yang meliputi kesalahan ejaan, diksi, dan keefektian kalimat. Kesalahankesalahan ini tentu harus diperbaiki bahkan diminimalisasi sedini mungkin karena jika tidak dapat menghambat proses pembelajaran ke depannya. Hal ini didukung oleh pendapat Kismawati, 
Sumarwati, Wadhani (2019:187) yang mengatakan bahwa apabila kesalahan berbahasa apabila tetap dibiarkan tanpa adanya upaya perbaikan maka akan menghambat peningkatan pengetahuan siswa terhadap kaidah bahasa yang dipelajarinya. Kesalahan berbahasa ini harus diperkecil atau bahkan dihindari. Salah satunya dengan menata komponen proses pembelajaran bahasa agar kegiatan pengajaran bahasa tersebut berhasil. Hal ini dapat dilalukan dengan menganalisis kesalahan berbahasa dan menemukan faktor penyebabnya. Selain kesalahan berbahasa, kesalahan penyusunan struktur teks atau karangan juga sering dilakukan siswa. Kebanyakan siswa kurang memamahi struktur-struktur penyusun sebuah teks.

Adanya analisis kesalahan struktur dan pemakian bahasa Indonesia dapat digunakan guru menganalisis permasalahan yang dialami siswa dalam hal menulis atau membuat karangan, terutama karangan persuasi. Hasil dari penelitian ini nantinya juga dapat digunakan sebagai masukan bagi guru untuk meningkatkan kemampuan menulis siswa, terutama dalam menulis teks persuasi. Oleh karena itu, peneliti membatasi fokus kajian penelitian meliputi kegiatan menganalisis kesalahan struktur dan kesalahan pemakaian bahasa Indonesia pada karangan persuasi yang ditulis oleh siswa kelas 8 SMP di Surakarta.

\section{METODE}

Penelitian dilaksanakan di dua sekolah, yaitu di SMP Negeri 3 Surakarta dan SMP Negeri 10 Surakarta. Metode penelitian yang digunakan dalam penelitian ini yaitu metode deskriptif kualitatif. Metode penelitian kualitatif menghasilkan data deskriptif yang berupa kata-kata lisan atau tertulis tentang sifat suatu keadaan, individu, gejala dari kelompok tertentu yang dapat diamati (Moleong, 2008:16). Pendekatan yang digunakan yaitu analisis isi (content analysis). Fraenkel dan Wallen (2007: 483) mengatakan bahwa analisis isi merupakan teknik yang dipakai oleh peneliti untuk mengkaji perilaku manusia secara tidak langsung melalui analisis terhadap cara berkomunikasi mereka.

Pengambilan sampel subjek penelitian menggunakan teknik purposive sampling. Purposive sampling ialah teknik pengambilan sampel dengan pemilihan subjek penelitiannya ditentukan oleh peneliti berdasarkan pertimbangan dan tujuan tertentu (Budiyono, 2017:153). Jumlah data teks persuasi yang diperoleh yaitu 60 teks. Sampel yang digunakan untuk diteliti yaitu 30 teks dengan kriteria karangan yang strukturnya hampir lengkap dan tulisan mudah dibaca. Peneliti juga mewawancarai guru mata pelajaran yang mengampu kelas 8 dan enam siswa guna memperoleh informasi dan data pendukung.

Teknik pengumpulan data pada penelitian ini dengan menggunakan 
analisis dokumen dan wawancara mendalam. Teknik uji validitas yang digunakan untuk menguji kebenaran data dalam penelitian ini menggunakan triangulasi teori dan triangulasi sumber. Teknik analisis data menggunakan model analisis data mengalir (flow analysis models) menurut Miles dan Huberman.

\section{HASIL DAN PEMBAHASAN}

Hasil penelitian yaitu diperoleh data berupa transkrip wawancara dan teks persuasi siswa yang berjumlah 60 dari dua sekolah. Diambil sebanyak 30 teks persuasi yang akan dijadikan sampel penelitian. Teks persuasi tersebut kemudian dianalisis untuk memperoleh data. Data yang diperoleh yaitu berupa kesalahan struktur dan pemakaian bahasa Indonesia pada teks persuasi siswa kelas 8 SMP di Surakarta. Kesalahan struktur dan pemakaian bahasa Indonesia yang ditemukan yaitu sebagai berikut.

\section{Kesalahan Struktur Teks Persuasi}

Kesalahan struktur teks persuasi yang dilakukan oleh siswa secara garis besar meliputi: struktur yang kurang lengkap dan pernyataan argumen yang tidak disertai data yang valid, kesalahan siswa dalam mengidentifikasi struktur, serta karangan persuasi disusun dengan struktur yang tidak lengkap dan tidak urut. Dari 30 sampel teks persuasi terdapat 15 siswa yang masih melakukan beberapa kesalahan.

Sebanyak 2 siswa (7\%) yang menuliskan teks tanpa di awali dengan pengenalan isu. Teks persuasi justru dibuka langsung dengan argumen. Sebanyak 2 siswa (7\%) yang menuliskan rangkaian argumen tanpa disertai data dan fakta yang valid sehingga argumennya masih kurang sahih. Terdapat 1 siswa (3\%) masih kurang tepat dalam menuliskan pernyataan ajakan. Kalimat-kalimat ajakan biasanya ditandai dengan kata seperti ayo, mari, dan sebagainya. Namun, siswa tidak menuliskan kalimat ajakan dan masih menuliskan serangkaian argumen. Sebanyak 7 siswa $(23 \%)$ tidak menuliskan penegasan kembali atau tidak membuat simpulan atas karangan persuasi yang dibuat. Siswa tersebut menutup teks persuasi dengan pernyataan ajakan. Terdapat 1 siswa (3\%) yang tidak menuliskan struktur teks persuasi dengan urutan yang tepat. Hal tersebut terjadi karena siswa justru menuliskan pernyataan ajakan kemudian baru diikuti rangkaian argumen. Seharusnya sebelum rangkaian argumen dipaparkan sebelum menyatakan ajakan kepada pembaca.

Kesalahan selanjutnya yaitu terdapat 4 siswa (13\%) yang justru menuliskan karangan yang mirip dengan teks berita. Kesalahan ini terjadi dikarenakan kesalahpahaman siswa dalam memahami instruksi dari guru. Ketika proses mengerjakan teks persuasi guru menginstruksikan siswa untuk membawa koran sebagai media untuk memproleh data dan fakta. Namun, hal ini justru dipahami siswa 
bahwa karangan persuasi merupakan teks yang ada di dalam koran.

Jenis kesalahan struktur teks persuasi pada penelitian ini serupa dengan hasil temuan Septiana, Sumarwati, dan Suyitno (2015:5) yang mengatakan bahwa kesalahan struktur yang sering dilakukan oleh siswa yaitu kesalahan urutan struktur sebuah teks. Diperkuat dengan hasil penelitian Sarwindah, Sumarwati, dan Mulyono (2019:45) yang mengatakan bahwa kesalahan struktur teks yang dilakukan siswa adalah struktur yang tidak urut dan kurang lengkap dalam penyusunannya sehingga kurang jelas.

\section{Kesalahan Penggunaan Ejaan}

Kesalahan ejaan merupakan salah satu bentuk kesalahan berbahasa yang sangat umum ditemukan dalam karangan yang ditulis oleh siswa. Penggunaan ejaan harus sesuai dengan PUEBI (Pedoman Umum Ejaan Bahasa Indonesia). Kesalahan ejaan yang ditemukan meliputi kesalahan pemakaian huruf kapital, penggunaan tanda baca, dan penulisan kata.

Kesalahan pemakaian huruf kapital yang ditemukan yaitu sebanyak 73 kasus kesalahan. Bentuk kesalahannya bermacam-macam, seperti tidak menggunakan huruf kapital pada huruf pertama awal kalimat, tidak menggunakan huruf kapital ketika menuliskan nama orang dan geografi, tidak menggunakan huruf kapital ketika menulis judul, dan sebagainya. Kesalahan tersebut antara lain yaitu sebagai berikut.
(1) "oleh karena itu, menjaga kebersihan lingkungan harus ditanamkan sejak dini." [data 1]

(2) "Walaupun sering sakit, tubuh rifky tetap gemuk dan perkembangannya normal.” [data 2]

(3) "Setidaknya beberapa minggu ke depan masyarakat indonesia akan melakukan PEMILU 2019." [data 3]

Pembenaran:

(1) "Oleh karena itu, menjaga kebersihan lingkungan harus ditanamkan sejak dini."

(2) "Walaupun sering sakit, tubuh Rifky tetap gemuk dan perkembangannya normal.

(3) "Setidaknya beberapa minggu ke depan masyarakat Indonesia akan melakukan pemilu 2019."

Pada [data 1] kesalahan terjadi karena huruf awal kalimat tidak ditulis menggunakan huruf kapital. Pada [data 2] kesalahan terjadi karena penulisan nama orang atau panggilan tidak ditulis menggunakan huruf kapital. Pada [data 3] kata 'PEMILU' seharusnya ditulis menggunakan huruf kecil semua karena bukan merupakan akronim nama diri.

Kesalahan penggunaan tanda baca yang ditemukan dalam karangan siswa yaitu sebanyak 60 kasus kesalahan. Sebanyak 35 kasus merupakan kasus kesalahan penggunaan tanda baca koma (,); 14 kasus merupakan kasus kesalahan penggunaan tanda baca titik (.); 10 kasus merupakan kasus kesalahan 
penggunaan tanda hubung (-); sisanya merupakan kasus kesalahan penggunaan tanda kurung ((..)). Kesalahan dapat dilihat pada data berikut.

(1) "Dengan demikian buku bisa dijadikan sebagai referensi, hiburan, dan sarana menambah ilmu." [data 4]

(2) "Saat musim hujan telah tiba, banyak sekali daerah daerah yang terkena banjir." [data 5]

Pembenaran:

(1) "Dengan demikian, buku bisa dijadikan sebagai referensi, hiburan, dan sarana menambah ilmu."

(2) "Saat musim hujan telah tiba, banyak sekali daerah-daerah yang terkena banjir."

Pada [data 4] data 'dengan demikian' merupakan kata penghubung antarkalimat. Penulisan kata hubung tersebut ditulis di awal kalimat dan diikuti oleh tanda koma (Pedoman Umum Ejaan Bahasa Indonesia, 2016:41). Pada [data 5] kata "daerah daerah" merupakan kata ulang sehingga penulisannya memerlukan tanda hubung.

Bentuk kesalahan penulisan kata yang ditemukan pada teks persuasi karangan siswa yaitu sebanyak 19 kasus kesalahan. Kesalahan penulisan kata yang dilakukan siswa cukup bervariasi, meliputi kesalahan penulisan kata depan, kata berimbuhan, gabungan kata, akronim, angka, dan partikel. Kesalahan tersebut antara lain sebagai berikut.
(1) "Berolahraga dipagi hari sangatlah penting bagi tubuh kita." [data 6]

(2) "Tetapi tidak semua salmon ada yang di masak matang."[data 7]

Pembenaran:

(1) "Berolahraga di pagi hari sangatlah penting bagi tubuh kita."

(2) "Tetapi tidak semua salmon ada yang dimasak matang."

Pada [data 6] penulisan 'di' pada kata 'dipagi' harusnya dipisah karena kata tersebut merupakan kata depan. Kesalahan penulisan kata berimbuhan, seperti contoh di bawah ini. Pada [data 7] penulisan 'di' seharusnya digabung dengan kata 'masak'. Hal tersebut dikarenakan kata 'di' tidak mewakili kata depan, tetapi kata imbuhan 'dimasak'.

\section{Kesalahan Pemilihan Diksi}

Terdapat 30 kasus kesalahan pemilihan diksi yang diakibatkan oleh ketidakbakuan kata, ketidaktepatan kata, dan ketidakekonomisan kata. Bentuk kesalahan pemilihan diksi yang diperoleh dari data penelitian antara lain sebagai berikut.

Data [8]

"Kita harus menjaga lingkungan, biar lingkungan kita menjadi bersih dan sehat."

Pembenaran:

"Kita harus menjaga lingkungan agar lingkungan kita menjadi bersih dan sehat."

Kata 'biar' biasanya digunakan sebagai kata penghubung yang berfungsi menyatakan hal-hal yang 
tidak bersyarat, seperti dalam kalimat 'Biar lambat asal selamat'. Oleh karena itu, kata penghubung 'biar' kurang cocok digunakan karena kalimat pada data (1) menandai adanya harapan (lingkungan menjadi bersih dan sehat). Jadi, kata penghubung yang cocok digunakan adalah kata 'agar'.

Data [9]

"Ketika obesitas menyerang, penyakit lain juga akan timbul."

Pembenaran:

"Ketika obesitas menyerang, penyakit lain juga akan muncul."

$$
\text { Penggunaan kata 'timbul' }
$$

kurang tepat. Hal ini dikarenakan kata 'timbul' biasanya digunakan untuk menggambarkan sebuah permukaan benda. Oleh karena itu, kata 'timbul' diganti dengan kata 'muncul' karena kata 'muncul' biasanya digunakan untuk menggambarkan tentang penyakit, perasaan, pikiran, dan sebagainya.

Data [10]

"Dokter mendiaknosa ia terkena infeksi saluran kencing."

Pembenaran:

"Dokter mendiagnosis ia terkena infeksi saluran kencing."

Kata 'mendiaknosa' merupakan kata tidak baku sehingga penggunaannya kurang tepat. Kata tersebut dapat diganti dengan kata baku, yaitu 'mendiagnosis'.

\section{Kesalahan Penulisan Kalimat}

Bentuk kesalahan penulisan kalimat yang diperoleh dari data sebagian besar disebabkan karena kalimat yang tidak efektif. Bentuk kesalahan ini dapat dilihat dalam penyajian kalimat yang boros kata dan bahasanya berbelit-belit. Selain itu, kesalahan juga disebabkan oleh kalimat yang tidak memiliki keutuhan. Berikut contoh kesalahan yang diperoleh dari hasil penelitian.

Data [11]

"Semakin besar isi kandungan tar dan nikotin dalam sebatang rokok maka makin besar dampak negatif yang diterima oleh tubuh kita. Dampak negatif bagi perokok aktif dan pasif."

"Diantaranya Penyakit jantung, kangker, serta impoten selain itu, gangguan kehamilan dan janin merupakan dampak negatif wanita yang menjadi perokok aktif."

Pembenaran:

"Semakin besar isi kandungan tar dan nikotin dalam sebatang rokok maka makin besar dampak negatif yang diterima oleh tubuh kita. Dampak negatif bagi perokok aktif dan pasif, diantaranya yaitu penyakit jantung, kanker, serta impoten. Selain itu, gangguan kehamilan dan janin merupakan dampak negatif bagi wanita yang menjadi perokok aktif."

Kalimat di atas seharusnya dijadikan satu paragraf karena masih memiliki satu kesatuan. Selain itu, sebelum kata 'wanita' lebih baik ditambahkan kata hubung 'bagi' agar tidak menimbulkan ketaksaan. Dengan demikian, paragraf tersebut lebih baik dijadikan satu karena kalimatnya masih memiliki kepaduan. 
Kesalahan penulisan kalimat pada teks persuasi siswa memiliki pola kesalahan yang hampir sama, yaitu (1) penulisan kalimat yang berbelit-belit; (2) kalimat terlalu panjang sehingga menimbulkan ketaksaan;

pemakaian kata penghubung dan kata depan yang tidak sesuai dengan fungsinya; (4) pemilihan diksi yang kurang tepat; (5) terdapat dua subjek dalam satu kalimat; (6) kalimat antarparagraf tidak memiliki kesinambungan \& kepaduan yang saling menjalin; dan (7) paragraf yang tidak memenuhi syarat karena hanya terdiri dari satu kalimat saja.

Kesalahan yang sering dijumpai dari ketiga aspek kesalahan di atas adalah kesalahan penggunaan ejaan. Senada dengan hasil penelitian Kismawati, Sumarwati, dan Wardhani (2019: 190) bahwa kesalahan berbahasa tertinggi terdapat pada bidang ejaan (45,25\%). Anjarsari, Suwandi, dan Mulyono (2013:7) juga menemukan hasil penelitian yang serupa, yaitu kesalahan berbahasa yang paling sering dilakukan adalah kesalahan ejaan (hampir 50\%) dibanding dengan tiga kesalahan bidang lain dalam penelitiannya.

\section{Faktor Penyebab Terjadinya} Kesalahan Struktur Teks Persuasi

Melalui hasil penelitian dengan analisis dokumen dan hasil wawancara yang telah dilakukan, peneliti menyimpulkan adanya faktor penyebab kesalahan struktur teks persuasi yaitu sebagai berikut.
Siswa Belum Memahami Strukturstruktur Teks Persuasi

Melalui proses wawancara terhadap siswa, dapat disimpulkan bahwa penyebab terjadinya kesalahan karena siswa kurang begitu paham dalam membedakan dan mengidentifikasi keempat struktur. Meskipun guru telah menerangkan materi, tetapi hal tersebut belum bisa memenuhi pemahaman siswa.

\section{Kesalahan Saat Menyampaikan Argumentasi dan Ajakan}

Ketika menyampaikan argumen harus disertai dengan data dan fakta yang valid. Namun, masih ada siswa yang dalam menuliskan argumennya tidak dukung dengan data yang meyakinkan pembaca. Bahkan, ada siswa yang menggunakan kata mungkin, yang mana kata mungkin menunjukkan ketidakpastian.

Pemanfaatan Media yang Tidak Tepat Sasaran

Pada proses pembuatan teks persuasi di SMP Negeri 10 Surakarta, guru memanfaatkan koran sebagai media untuk memperoleh data dan fakta pendukung argumen. Namun, penggunaan koran justru menjadikan salah tafsir bagi siswa sehingga siswa mengira bahwa teks persuasi sejenis dengan teks berita yang ada di koran. Padahal kedua teks berbeda struktur.

Perbedaan Guru dan Buku Materi dalam Memaparkan Struktur Teks Persuasi

Guru menjelaskan struktur teks persuasi ada tiga, yaitu fakta, argumen, dan ajakan. Akan tetapi, dalam buku

BASASTRA Jurnal Bahasa, Sastra, dan Pengajarannya 
teks dijelaskan bahwa ada empat struktur, yaitu pengenalan isu, rangkaian argumen, pernyataan ajakan, dan penegasan kembali.

\section{Kurangnya Contoh yang Diberikan Guru}

Dari hasil wawancara siswa mengeluhkan belum memahami materi karena kurangnya contoh yang diberikan guru. Selain itu, seorang guru juga hanya menggunakan satu metode pembelajaran yakni metode ceramah sehingga keefektifannya dalam menyampaikan dan menjelaskan materi belum maksimal.

\section{Faktor Penyebab Terjadinta Kesalahan Pemakaian Bahasa Indonesia}

Kesalahan pemakaian bahasa Indonesia disebabkan oleh faktorfaktor, yaitu sebagai berikut.

\section{Siswa Minim Pengetahuan Tentang Ejaan dan Diksi}

Dilihat pada hasil penelitian bahwa masih terdapat kesalahankesalahan ejaan dan diksi. Ketika peneliti menanyakan pengertian ejaan dan diksi kepada siswa, semua siswa menjawab tidak tahu. Hal inilah yang menjadi penyebab siswa tidak memperhatikan ejaan dan pemilihan kata-kata ketika menulis teks persuasi.

\section{Kurangnya Latihan Mengarang}

Melalui hasil wawancara diketahui bahwa siswa memang jarang menulis. Apabila siswa terbiasa dan dilatih untuk menulis terus-menerus, tentu kualitas tulisannya akan menjadi lebih baik. Biasanya siswa hanya menulis untuk memenuhi kebutuhan tugas yang mengharuskan siswa membuat sebuah teks atau karangan.

\section{Kurangnya Motivasi Siswa dalam Menulis atau Mengarang}

Melalui proses wawancara diperoleh informasi bahwa siswa kurang suka menulis, terlebih menulis karangan. Beberapa siswa lebih menyukai menulis karya sastra seperti menulis puisi dan cerpen karena penulisannya tidak terikat oleh struktur dan kiadah bahasa tertentu. Selain itu, program literasi belum terlaksana sebagai mana mestinya padahal kegiatan ini dapat dimanfaatkan sebagai media untuk memotivasi siswa agar terbiasa membaca dan menulis.

Faktor-faktor yang dijelaskan diatas serupa dengan hasil temuan Ariningsih, Sumarwati, dan Saddhono (2012: 46) bahwa faktor yang menyebabkan kesalahan berbahasa, yaitu penguasaan kaidah berbahasa yang kurang memadai, kurangnya contoh yang diajarkan guru, adanya pengaruh dari bahasa asing, kurangnya latihan menulis atau mengarang, dan kurangnya waktu yang diberikan untuk mengarang. Nurhayatin, Inggriyani, dan Ahmad (2018: 111) dalam penelitiannya menemukan faktor kesalahan penggunaan kalimat efektif disebabkan oleh ketidaktahuan tentang kaidah bahasa serta kurangnya motivasi dalam menulis.

Faktor terjadinya kesalahan tidak hanya disebabkan oleh siswa, tetapi juga disebabkan oleh guru. Guru 
menjelaskan materi pelajaran hanya menggunakan metode ceramah. Hal ini kurang efektif karena contoh yang diberikan kurang bervariatif. Oktaviani, Rohmadi, dan Purwadi (2018: 105) menemukan dalam penelitian bahwa faktor kesalahan berbahasa juga disebabkan oleh guru, yaitu kurangnya variasi metode pembelajaran yang digunakan oleh guru.

Adanya kesalahan struktur dan kesalahan pemakaian bahasa Indonesia pada teks persuasi karangan siswa harus diminimalisasi bahkan diatasi agar nanti dikemudian hari kesalahan tersebut tidak terulang atau terjadi kembali. Upaya yang dapat dilakukan untuk mengatasi kesalahan tersebut antara lain sebagai berikut.

\section{Meningkatkan Kualitas Proses Pembelajaran di Kelas}

Kurangnya pemahaman siswa tentang struktur teks dapat disebabkan oleh pembelajaran yang membosankan. Oleh karena itu, perlu adanya peningkatan kualitas proses pembelajaran di kelas. Salah satunya yaitu dengan menerapkan metode atau model pembelajaran lain selain ceramah. Awalludin (2018: 165) dalam hasil penelitiannya menyebutkan bahwa penerapan model pembelajaran desicion making dapat meningkatkan kualitas menulis karangan persuasif siswa. Effendi dan Emzir (2018: 235) menemukan bahwa penggunaan model pembelajaran learing cycle efektif meningkatkan kualitas menulis siswa dan meminimalisasi kesalahan struktur dan kebahasaan yang dilakukan siswa.

Selain itu, guru dapat menerapkan koreksi antar teman untuk meningkatkan keaktifan siswa dalam proses pembelajaran. Koreksi antar teman juga efektif meningkatkan kualitas tulisan. Hal ini dibuktikan oleh hasil penelitian Ulfah (2013:11) yang menemukan bahwa penerapan teknik peer-correction dapat memengaruhi dan meningkatkan kualitas proses pembelajaran pada kompetensi menulis karya ilmiah.

\section{Meningkatkan Penguasaan Kaidah Kebahasaan Siswa}

Banyak siswa yang mengaku belum paham mengenai tata bahasa atau kaidah bahasa yang baik dan benar, bahkan mereka tidak tahu tentang ejaan dan diksi. Hal ini menjadi pemicu masih banyak ditemukan kesalahan berbahasa dalam tulisan atau karangan yang dibuat oleh siswa. Oleh karena itu, siswa hendaknya memperluas penguasaan dan pengetahuan kaidah kebahasaan dengan memperbanyak literatur atau artikel jurnal mengenai kaidah bahasa Indonesia. Siswa juga dapat membaca Pedoman Umum Ejaan Bahasa Indoensia (PUEBI).

Ayudia, Suryanto, dan Waluyo (2016: 47) menyarankan agar pihak sekolah dapat menyediakan sumber bacaan atau sumber pustaka yang memadai, misalnya dengan menyediakan dan melengkapi koleksi buku keterampilan menulis, KBBI, EYD, dan lain-lain. Hal ini dapat

BASASTRA Jurnal Bahasa, Sastra, dan Pengajarannya

Volume 8 Nomor 2, Oktober 2020, P-ISSN 2302-6405, E-ISSN 2714-9765 
membuat siswa lebih mudah lagi untuk mengakses bahan pustaka mengenai kaidah kebahasaan.

\section{Memperbanyak latihan menulis}

Apabila siswa sering melakukan kegiatan menulis tentu hal ini dapat meningkatkan kualitas tulisan. Peran guru dibutuhkan untuk memotivasi siswa agar rajin dalam menulis dan tidak hanya menulis saat diberikan tugas saja. Setyawan, Andayani, dan Wardhani (2015: 15) menyimpulkan bahwa guru harus mampu menumbuhkan motivasi siswa dengan berbagai macam cara, seperti mensugesti kepercayaan diri siswa, menggunakan metode pembelajaran yang menarik, dan menciptakan susana belajar mengajar yang menyenangkan dan kondusif.

\section{SIMPULAN}

Berdasarkan hasil penelitian terhadap karangan teks persuasi kelas 8 SMP di Surakarta, diambil beberapa simpulan. Pertama, kesalahan struktur teks persuasi yang dilakukan siswa meliputi: kesalahan dalam membuat argumen yang tidak disertai data dan fakta yang valid, kesalahan siswa dalam mengidentifikasi struktur, serta karangan persuasi disusun dengan struktur yang tidak urut dan tidak lengkap. Ketidaklengkapan struktur utamanya pada bagian penegasan ulang.

Kedua, kesalahan berbahasa atau pemakaian bahasa Indonesia pada teks persuasi siswa meliputi kesalahan penggunaan ejaan, kesalahan pemilihan diksi, dan kesalahan penulisan kalimat. Terdapat tiga jenis kesalahan penggunaan ejaan yang ditemukan pada teks persuasi karangan siswa, yaitu kesalahan pemakaian huruf kapital sebanyak 73 kasus, kesalahan penggunaan tanda baca sebanyak 60 kasus, dan kesalahan penulisan kata sebanyak 19 kasus. Terdapat 27 kasus kesalahan pemilihan diksi dan 10 kasus kesalahan penulisan kalimat yang dilakukan oleh siswa.

Ketiga, kesalahan siswa dalam memahami struktur teks persuasi disebabkan oleh beberapa faktor, yaitu (a) siswa belum memahami strukturstruktur teks persuasi; (b) kesalahan saat menyampaikan argumen dan ajakan; (c) pemanfaatan media yang tidak tepat sasaran, (d) perbedaan guru dan buku materi dalam memaparkan struktur teks persuasi; dan (e) kurangnya contoh yang diberikan guru.

Keempat, kesalahan berbahasa atau pemakaian bahasa Indonesia pada teks persuasi yang ditulis siswa disebabkan oleh beberapa faktor, yaitu (a) siswa minim pengetahuan tentang ejaan dan diksi; (b) kurangnya latihan mengarang; dan (c) kurangnya motivasi siswa dalam menulis.

\section{REFERENSI}

Angriani, P. \& Maharani, I. (2019). Pengaruh Media Iklan Audio Visual terhadap Keterampilan Menulis Teks Persuasi Siswa Kelas VIII SMP Negeri 15 
Palembang. Prosiding Seminar Nasional.

Anjarsari, N., Suwandi, S., \& Mulyono, S. (2013). Analisis Kesalahan Pemakaian Bahasa Indonesia dalam Karangan Mahasiswa Penutur Bahasa Asing di Universitas Sebelas Maret. BASASTRA: Jurnal Pendidikan Bahasa, Sastra Indonesia, dan Pengajarannya, 2(1), 1-13.

Ariningsih, N.E., Sumarwati, \& Saddhono, K. (2012). Analisis Kesalahan Berbahasa Indonesia dalam Karangan Eksposisi Siswa Sekolah Menengah Atas. BASASTRA: Jurnal Pendidikan Bahasa, Sastra Indonesia, dan Pengajarannya, 1(1), 40-53.

Awalludin. (2018). Efektivitas Model Decision Making dalm Pembelajaran Menulis Paragraf Persuasif Siswa Kelas X SMK Trisakti Baturaja. Jurnal Bindo Sastra, 2(1), 159-167.

Ayudia, Suryanto, E., \& Waluyo, B. (2017). Kesalahan Penggunaan Bahasa Indonesia dalam Laporan Hasil Observasi Siswa Sekolah Menengah Pertama. BASASTRA: Jurnal Pendidikan Bahasa, Sastra Indonesia, dan Pengajarannya, 5(2), 1-16.

Budiyono. (2017). Pengantar Metodologi Penelitian Pendidikan. Surakarta: UNS Press.

Dalman. (2012). Keterampilan Menulis. Depok: PT Rajagrafindo Persada.

Effendi, R. \& Emzir. The Improvement of Students Ability to Write Exposition Text through Learning Cycle Model. Journal of Education, Teaching, and Learning, 3(2), 233-236.
Fraenkel, J.P. \& Wallen, N.E. (2007). Ho to Design and Evaluate Research in Education. New York: McGraw-Hill Companies, Inc.

Javed, M., Juan, W.X., \& Nazli, S. (2013). A Study of Student Assessment in Writing Skills of the English Language. International Journal of Instruction, 6(2), 129-144.

Kemendikbud. (2016). Pedoman Umum Ejaan Bahasa Indonesia. Jakarta: Badan Pengembangan dan Pembinaan Bahasa.

Keraf, G. (2007). Argumentasi dan Narasi. Jakarta: PT Gramedia Pustaka Utama.

Kismawati, U., Sumarwati, \& Wardhani, N.E. (2019). Kesalahan Berbahasa pada Karangan Eksposisi Siswa Sekolah Menengah Atas: Bentuk, Faktor Penyebab, dan Upaya Mengatasi. BASASTRA: Jurnal Pendidikan Bahasa, Sastra Indonesia, dan Pengajarannya, 6(2), 185-196.

Moleong, L. (2008). Metodologi Penelitian Kualitatif. Bandung: Remaja Rosdakarya.

Nurgiyantoro, B. (2014). Penilaian Pembelajaran Bahasa Berbasis Kompetensi. Yogyakarta: BPFE.

Nurhayatin, T., Inggriyani, F., \& Ahmad, A. (2018). Analisis Keefektifan Penggunaan Kalimat dalam Karya Tulis Ilmiah Mahasiswa Pendidikan Guru Sekolah Dasar. JPSD, 4(1), 102114.

Oktaviani, F., Rohmadi, M., \& Purwadi. (2018). Analisis Kesalahan Berbahasa Indonesia pada Karangan Eksposisi Siswa Kelas X MIPA (Studi Kasus di 
SMA Negeri 4 Surakarta. BASASTRA: Jurnal Pendidikan Bahasa, Sastra Indonesia, dan Pengajarannya, 6(1), 94-109.

Purwaningrum, S.W., Andayani, Purwadi. (2013). Penggunaan Metode Peta Pikiran (Mind Mapping) untuk Meningkatkan Kemampuan Menulis Narasi Siswa Sekolah Menengah Pertama. BASASTRA: Jurnal Pendidikan Bahasa, Sastra Indonesia, dan Pengajarannya, 2(1), 1-13.

Sarwindah, D., Sumarwati, \& Mulyono, S. (2019). Kesalahan Struktur Teks dan Kebahasaan Laporan Hasil Observasi: Studi Kasus di SMP Kristen 1 Surakarta. BASASTRA: Jurnal Pendidikan Bahasa, Sastra Indonesia, dan Pengajarannya, 7(2), 43-48.

Septiana, A.N.S., Sumarwati, \& Suyitno. Analisis Kesalahan Struktur Teks dan Pemakaian Bahasa Indonesia pada Teks Biografi Karya Siswa SMP. BASASTRA: Jurnal Pendidikan Bahasa, Sastra Indonesia, dan Pengajarannya, 3(3), 1-13.

Setyawan, A., Andayani, Wardhani, N.E. (2015). Hubungan Antara Penguasaan Kosakata dan Motivasi Belajar dengan Keterampilan Menulis Teks Narasi pada Siswa Kelas XI SMK Negeri 1 Sawit Boyolali Tahun Ajaran 2014/2015. BASASTRA: Jurnal Pendidikan Bahasa, Sastra Indonesia, dan Pengajarannya, 3(2), 1-16.

Ulfah, M., Fuady, A., \& Wardani, N.E. (2013). Teknik Peer-Correction untuk Meningkatkan Kualitas
Proses dan Hasil Pembelajaran Menulis Karya Ilmiah Siswa Sekolah Menengah Atas. BASASTRA: Jurnal Pendidikan Bahasa, Sastra Indonesia, dan Pengajarannya, 2(1), 1-12. 